\title{
Brucella abortus S-19 Aşısının Liyofilizasyon Öncesi Farklı Liyoprotektanlar ile Kritik Formülasyon Sıcaklıklarının Araştırılması
}

\author{
Mustafa Sencer Karagüli ${ }^{1}$, Buket Eroğlu \\ ${ }^{1}$ Kocaeli Üniversitesi Kartepe Atçıllk Meslek Yüksekokulu, Kocaeli \\ ${ }^{2}$ Pendik Veteriner Kontrol Enstitüsü, İstanbul
}

Geliş Tarihi / Received: 14.04.2019, Kabul Tarihi / Accepted: 30.05.2019

\begin{abstract}
Özet: Bu çalışmada, Brucella abortus S19 aşı şuşu ile liyoprotektan karışımlarının termal analizi yapılarak kritik formülasyon sıcaklıklarının belirlenmesi, karşılaştırmalı sonuçlar ile liyofilizasyon optimizasyonu için istifade edilebilecek bilgilere ulaşılması amaçlanmıştır. S19 aşısı ile 3 farklı liyoprotektan (mannitol, sukroz, trehaloz) 3 farklı konsantrasyonda (\%5, \%10, \%15) kullanılarak 9 farklı formülasyonun analizi termal görüntüleme cihazı olan dondurarak kurutma mikroskopu (FDM) ve Diferansiyel Termal Analiz (DTA) ile elektriksel direnç (Zsin) analizini sağlayan termal analiz cihazı ile yapılmıştır. Termal analiz ve görüntüleme cihazların kullanımıyla elde edilen kritik formülasyon sıcaklıkları ile liyoprotektan tercihi ve konsantrasyonu arasındaki ilişki araştırılmıştır. Aşı yarı mamulü ile liyoprotektantan oluşan formulasyon içeriğinde liyoprotektan değiştirildiğinde formulasyonun kritik sıcaklık değerinde de kayda değer farklar, gözlenmiştir. Her liyoprotektanın farklı konsantrasyonda kullanımında ise kurutma prosesinin yeni baştan dizayn edilmesini gerektiren farklar tespit edilmemiştir. Sonuç olarak çalışma sonucunda elde edilen bulguların gelecek çalışmalar için oluşturulmuş temel bir reçete üzerinden protektan madde konsantrasyonunun arttırılarak yapılacak liyofilizasyon proseslerinin yürütülmesi ile verim ve stabilitenin arttırılabileceği kanısına varılmıştır.
\end{abstract}

Anahtar kelimeler: B. abortus S-19, Liyofilizasyon, Liyoprotektan, Termal Analiz.

\section{Investigating the Critical Formulation Temperatures of Brucella Abortus S-19 Vaccine With Different Liyoprotectants Prior to Liyophilisation}

\begin{abstract}
The aim of this study is to determine the critical temperatures of formulations composed of Brucella abortus S19 vaccine strain and liyoprotectants. It also attempts to obtain the necessary information that may be beneficial for the optimization of liyophilisation process by the help of comparative results among formulations. Thermal analysis of 9 different formulations consisting of S19 strain and each of 3 lyoprotectants (mannitol, sucrose, trehalose) at 3 different concentrations $(5 \%, 10 \%, 15 \%)$ was carried out by freeze drying microscopy (FDM), differential thermal analysis (DTA), and electrical impedance (Zsin) analysis. Correlations between liyoprotectant choice and liyoprotectant concentration were investigated by the help of critical formulation temperatures obtained through thermal analysis and screening instruments. Significant differences in the critical temperature of vaccine with liyoprotectant formulation were observed when a different liyoprotectant was used. However, differences that require the redesign of the whole drying process were not observed at the different concentrations of the same liyoprotectant. In conclusion, in the guide of a baseline recipe, evaluation of the liyophilisation process carried out through increasing the amount of liyoprotectant can be recommended to increase stability and performance.
\end{abstract}

Key words: B. abortus S-19, Liyophilisation, Liyoprotectant, Thermal Analysis.

\section{Giriş}

Liyofilizasyon, endüstrinin ve bilimin farklı dallarında yaygın olarak kullanılmaktadır. Biyolojik materyallerin preservasyonundaki kullanımı da kayda değer seviyededir. Bu bağlamda liyofilizasyon, özellikle liyofilize formdaki zayıflatılmış aşıların üretim zincirinde önemli bir basamağı oluşturmaktadır. Liyofilizasyon basamaklarının, liyofilize edilecek ürünün formülasyon özelliklerine göre oluş- turulmas1, üretim zincirindeki diğer basamaklar ile aynı seviyede önem taşımaktadır. Bir liyofilizasyon döngüsünün oluşturulmasında birincil ve en önemli basamak formülasyonun karakterize edilmesidir [11]. Formülasyonların, prosese bağlı ürün kusurlarını önlemek adına soğutulduğu ve birincil kurutma süresince aynı düşük sicaklık derecesinin korunduğu kritik bir sıcaklığı bulunmaktadır [22]. Söz konusu kritik sıcaklıklar amorf ürünler için kollaps-çökme sıcaklığı $(\mathrm{Tc})$ veya cam geçiş sıcaklığ ${ }^{(T g}$ ') ve 
kristalin yapılar için ötektik (Teu) erime noktasıdır $[8,12]$. Tc değeri materyalin yumuşayarak yapısını koruyamadığ 1 sıcaklık noktasıdır. Çözünen materyalin eridiği ve çözücü ayrıldıktan sonra herhangi bir yapının oluşamadığı sıcaklık noktası da "Teu" olarak tanımlanmaktadır. "Tg" ise donmuş materyalin kırılgan formu yitirip esneklik kazandığı sıcakl1k değeridir [22]. Formülasyonların kritik sıcaklık değerleri, ürüne ait hassas özellikler arasında temel noktada bulunmaktadir.

Liyofilize bir formülasyon çok farklı yardımcı maddeler içerebilmektedir [26]. Liyofilizasyonda tercih edilen liyoprotektan gibi bazı yardımcı maddelerin hem dondurma hem de kurutma basamaklarında stabilizasyon sağladıkları paylaşılmıştır [17]. Liyoprotektan gibi ara maddeler, kimyasal olarak hassas biyoaktif bileşenler için koruma sağlayabilmektedirler [7]. Trehaloz, sukroz ve maltoz gibi dissakaridlerin, dondurma ve kurutmada stabilizasyon sağlayabildikleri bildirilmiştir [17]. Sukroz gibi sakkaridler genellikle suyun uzaklaşmasından kaynaklı denatürasyona karşı protein konformasyonunu korumak için kullanılmaktadır. Dissakkarid ajanlar haricinde mannitol ise hacim arttırıcı olarak formülasyonlarda sıklıkla kullanılmaktadır [11,23]. Mannitol ayrıca sahip olduğu yüksek Teu değeri ile birincil kurutmanın kolay ve hızlı olmasını sağlamaktadır [26]. Hacim arttırıcı ajanlar, toplam katı içeriğini arttırarak mekanik olarak daha dirençli bir ürün dolgusu oluşturmak için kullanılmaktadır [8]. Prosesin birinci basamağ 1 olan dondurmanın kontrolü ürün kalitesi ve prosesi optimize etmek adına son derece önemlidir [13]. Bu bakımdan dondurma prosesinin, reçeteye dökülmesinde ürüne ait kritik sıcaklıkları temsil eden Teu, Tc ve Tg' değerlerinin göz önünde bulundurulması çok önemlidir [6]. Söz konusu kritik formülasyon sıcaklıkları, tercih edilen yardımcı ajanlara göre farklılık gösterebilmektedir. Liyofilizasyon döngüsünü tam olarak optimize etmek için en önemli yol, sublimasyon devam ederken formülasyonun ürün sıcaklığını "kritik s1caklığına" yakın fakat aşmayacak seviyede kontrol etmektir. Bu amaçla yardımcı maddelerin ve final formülasyonun termal davranışını belirlemek için çeşitli yöntemler kullanılmaktadır. En sık kullanılan teknikler FDM ile DTA ve/veya Zsin analizleridir [18]. Formülasyonun fiziko-kimyasal halinden kaynaklı olarak prosesin uygulama sıcaklığı, aşılmaması gereken maksimum müsaade edilebilir ürün sıcaklığg ile sınırlıdır. Bu sıcaklık, "kritik formülasyon sicaklığı" olarak tanımlanmaktadır [15]. Dondurarak kurutma prosesi için kurutulacak formülasyonların kritik parametrelere göre analiz edilmesi gereklidir. Tc değeri sıklıkla FDM ile tespit edilmektedir $[9,10]$. Bu amaçla değişken sıcaklık ve vakum altında kurumakta olan ürüne ait numunenin gözlemlenmesine izin veren FDM cihazı ile kritik formülasyon sıcaklıkları belirlenebilmektedir [8]. Tg' analizi için kullanılan DTA ise, bir örneğin ve bir referansın (genellikle örneği hazırlamak için kullanılan su ile aynı standartta) birebir aynı koşullarda soğuma ve ısınmasını içeren, bu esnada ürün ve referanstaki sıcaklık değişimlerini gözlemleyerek bu gözlemi sıcaklık veya zaman işlevi içinde grafiklendiren bir teknik olarak tanımlanmaktadır [27]. DTA analiz cihaz1, DTA ve Zsin analiz kabiliyetini beraber taşımaktadır [21].Termal analiz ve görüntüleme cihazlarının etkin seviyede kullanımı proses geliştirilmesinde ve araştırma-geliştirme çalışmalarında zaman tasarrufu ve maliyet düşüşü sağlayabilecektir.

Liyofilizasyon genellikle zaman alıcı bir prosestir ve özellikle optimum döngü koşulları tasarlanmadığ1 zaman gereksiz yere daha uzun birincil kurutma sürelerine ihtiyaç duyulmakta ve dolay1sıyla daha masraflı bir işleme dönüşebilmektedir $[12,18]$. Uygun liyofilizasyon reçetesinin oluşturulmas1 ve sonraki basamaklara devam edilmesi formülasyonun kritik sicaklık parametrelerindeki gerekliliklere riayet edilmesine bağlıdır. Bu bakımdan liyofilizasyon işlemine başlamadan önce dondurma ve kurutma basamakları tasarlanırken kesinlikle prosese maruz kalacak ürün özellikleri ve solut-solvent muhteviyatı ile konsantrasyonu göz önünde bulundurulmalıdır.

Zoonoz bir hastalık olan bruselloz, sığırlarda yavru atmaya yol açarak ekonomik kayıplara neden olmakta, hayvan ve toplum sağllğ 1 için de risk oluşturmaktadır. Bu çalışmanın amacı sığır brusellozuna karşı kontrol ve eradikasyon çalışmalarında yaygın olarak kullanılan S19 aşısına ait kritik formülasyon sicaklıklarını farklı liyoprotektanlar kullanılarak belirlemektir. Elde edilen veriler, S19 aşısı için liyobilizasyon kaybını azaltan ve stabiliteyi artıran uygun liyofilizasyon reçetelerinin kurgulanması için basamak oluşturmaktadır. 


\section{Materyal ve Metod}

Kullanılan aşı suşu ve liyoprotektanlar: Bu çalışmada, B. abortus S19 aşı suşu ve 3 farklı liyoprotektan kullanılmıştır. S-19 aşı suşu üretimi Pendik Veteriner Kontrol Enstitüsü Brusella Referans ve Aş1 Üretim Laboratuvarında S-19 ana tohum suşundan (ATS-PVKEA-13-04) yapılmıştır. Sukroz (Cas No: 57-50-1), Trehaloz (Cas No: 6138-23-4) ve Mannitol (Cas No:69-65-8) her biri \%5, \%10 ve \%15'lik konsantrasyonda kullanılmıştır.

Kullanılan Termal Analiz ve Görüntüleme Cihazları (FDM, DTA): Termal görüntüleme ve analiz için FDM ve DTA cihazları kullanılmıştır.

\section{B. abortus S-19 aşı yarı mamulü ile liyoprotek-} tanların birleştirilmesi: Ana tohum suşundan pasajlanan çalışma tohum şuşu ile biyoreaktörde aş1 suşu üretimi yapılmıştır. Biyoreaktörde üretilen S-19 aş1 yarı mamulünün konsantrasyon işlemi sonrası, seyreltme yöntemiyle canlılık sayımı yap1larak, yarı mamulün bakteri yükü $1410 \times 10^{9} \mathrm{kob} / \mathrm{ml}$ olarak tespit edilmiştir [2]. Üretim sonrası canlılık sayımı ile bakteri yükü (kob/ml) belirlenmiş olan yarı mamul aşı ürünü her bir liyoprotektanın farklı konsantrasyonları ile seyreltilerek final yarı mamul aş1 ürünü oluşturulmuştur. Her bir konsantrasyondaki liyoprotektanlar ile aşı bulk ürünü, 9,4 kat sulandırılarak, formülasyonun S-19 şuş yükü $150 \times 10^{9}$ $\mathrm{kob} / \mathrm{ml}$ olarak düzenlenmiştir.

Kritik formülasyon sıcaklıklarının tespit edilmesi (FDM, DTA, Zsin): FDM ile numunelerin çalışması sırasında, 16-20 mm çapında ince bir cam slayt dondurarak kurutma aşamasının gerçekleşeceği gümüş blok üzerine yerleştirildi. Örnek çözeltinin yaklaşık $2 \mu$ l'si her deney sırasında bu cam slayt üzerine konulup, daha ince ve daha küçük (10-13 mm) bir cam slayt, numune damlacığ1nın üstüne yerleştirildi [16]. Numunenin analizi için cihaza bağlı bilgisayarda tanımlanmış bir sıcaklık profili seçildi. $\mathrm{Bu}$ profile göre $20^{\circ} \mathrm{C} / \mathrm{dk}$ 'lık soğutma ivmesi ile ürün $-40^{\circ} \mathrm{C}$ 'ye ulaştırıldı. Bu sıcaklık noktasına ulaşana kadar 60 saniye aralıklarla cihazın kamerası ile örnek görüntüsünün resmi çekildi. Ardından vakum pompası devreye alındı.Numune, çökme noktası boyunca bir $1^{\circ} \mathrm{C} / \mathrm{dk}$ düşüş hızı kullanılarak 1sitılmış ve bu süre boyunca süblimasyon ara yüzeyindeki yapı kayıplarının durumu (boşluklar, delikler, çatlaklar, vb.) incelenerek kollaps s1- caklığı belirlenmiştir [16]. Isıtma aşamasında her 5 saniyede bir otomatik olarak mikroskoptaki görüntünün resmi çekilerek, üründeki termal değişim kısa zaman aralığında çekilen resimlerin gözlemlenmesi ile değerlendirilmiştir.

Zsin ve DTA analizinde, referans ve numunenin sıcaklığa karşı hem solüsyon impedansı hem de solüsyon donarken, erirken veya yumuşarken ki ekzotermik ve endotermik değişiklikler DTA analizi ile grafiklendirilir [3]. Zsin ve DTA analizi, her bir numune ( $3 \mathrm{ml})$ üzerinde aynı anda gerçekleştirilmiştir. Örnek ve referans malzeme paslanmaz çelik örnek hücrelerine konularak, cihaza ait Sıvı nitrojen tankı ile $100{ }^{\circ} \mathrm{C}$ 'nin altına soğutulmuş ve ardından örnek taşıyıcı hücreler tanktan yukarı alınarak 1sıtma işlemi başlatılmıştır ve tüm problar $0^{\circ} \mathrm{C}$ 'nin üzerini gösterene kadar örnekler 1sıtılmıştır. Her bir örnek hücresinde yer alan problar sayesinde termal değişikliklere ve iyonik hareketliliğin artmasına bağlı olarak, solüsyonlarda meydana gelen önemli olayların sıcaklıklarının belirlenmesi, 1sınma profilinin yorumlanması ve çizilmesi için ham veriler doğrudan excel dosyasına aktarılmıştır [3].

\section{Bulgular}

Çalışma için seçilen liyoprotektanların ve aşı yarı mamul ürünü ile liyoprotektan birleşimi olan formülasyon numunelerinin 3 tekrarlı olarak yapılan analizlerin ortalama sonuçları Tablo-1'de listelenmektedir.

Aş1 yar1 mamulü ilavesi öncesi yapılan analizlerde farkl1 konsantrasyonlardaki salt sukroz, trehaloz ve mannitol solüsyonları arasında FDM cihazında kollaps sıcaklığı olarak elde edilen sıcaklık dereceleri arasında sirasıyla en yüksek 1,$1 ; 0,5$ ve $0,2^{\circ} \mathrm{C}$ fark olan, birbirine çok yakın sıcaklık noktaları tespit edilmiştir. Aynı numunelerin DTA ve Zsin analiz sonuçları FDM de tespit edilenlerden daha düşük sıcaklık noktaları olmuştur. Farklı konsantrasyonlardaki salt sukroz solusyonlarına ait DTA ve Zsin analiz sonuçlarının kendi arasındaki en büyük fark ise sırasiyla 4,62 ve $2,71^{\circ} \mathrm{C}$ olarak bulunmuştur. Bu sıcaklık farkı trehaloz örnekleri için sırasıyla 1,58 ve 1,53 olarak mannitol örnekleri için 1,14 ve $0,67^{\circ} \mathrm{C}$ olarak belirlenmiştir. Mannitolün, Zsin ve DTA analizi sonucu elde edilen kritik sicaklıklar Grafik-1'de yer almaktadır. Sukroz ve trehaloza göre daha yüksek sıcaklık noktaları tespit edilmiştir. 
Tablo-1: Numunelerin FDM, Zsin ve DTA analizlerinde elde edilen kritik formülasyon sıcaklıkları.

\begin{tabular}{|c|c|c|c|}
\hline Numune & FDM $\left({ }^{\circ} \mathrm{C}\right)$ & $\mathrm{Zsin}\left({ }^{\circ} \mathrm{C}\right)$ & DTA $\left({ }^{\circ} \mathrm{C}\right)$ \\
\hline Sucrose $\% 5$ & $-32,1$ & $-37,22$ & $-36,64$ \\
\hline Sucrose $\% 10$ & $-31,1$ & $-34,51$ & $-37,72$ \\
\hline Sucrose $\% 15$ & $-30,9$ & $-36,88$ & $-33,10$ \\
\hline Sucrose $\% 5+$ S19 & $-30,96$ & - & $-31,4$ \\
\hline Sucrose $\% 10+$ S19 & $-31,73$ & - & $-33,6$ \\
\hline Sucrose $\% 15+$ S19 & $-30,75$ & - & $-35,21$ \\
\hline Trehalose $\% 5$ & $-27,27$ & $-36,97$ & $-32,33$ \\
\hline Trehalose $\% 10$ & -28 & $-38,5$ & $-32,43$ \\
\hline Trehalose $\% 15$ & $-27,5$ & $-38,2$ & $-30,85$ \\
\hline Trehalose $\% 5+$ S19 & $-28,23$ & - & -32 \\
\hline Trehalose $\% 10+$ S19 & $-27,40$ & - & $-33,25$ \\
\hline Trehalose $\% 15+$ S19 & $-26,53$ & - & $-31,73$ \\
\hline Mannitol $\% 5$ & $-1,6$ & $-3,35$ & $-3,42$ \\
\hline Mannitol $\% 10$ & $-1,4$ & $-2,68$ & $-4,13$ \\
\hline Mannitol\%15 & $-1,5$ & $-2,98$ & $-4,56$ \\
\hline Mannitol\%5 + S19 & -5 & - & $-6,9$ \\
\hline Mannitol $\% 10+$ S19 & $-4,5$ & - & $-6,32$ \\
\hline Mannitol\%15 + S19 & $-2,8$ & - & $-6,43$ \\
\hline
\end{tabular}

Aşı yarı mamulü ilavesi sonrası yapılan analizlerde aşı ürünü ile beraber farklı konsantrasyonlarda sukroz, trehaloz ve mannitol içeren formülasyonların kendileri arasında konsantrasyon farkına bağlı FDM cihazında kollaps sıcaklığg olarak elde edilen sıcaklık değerleri arasında sirasıyla en yüksek $0,98,1,7$ ve $2,2^{\circ} \mathrm{C}$ fark olan, birbirine çok yakın sıcaklık noktaları tespit edilmiştir. Resim-1'de \%15 Sukroz+S19 aşı formülasyonunda meydana gelen kollaps, FDM cihazında $-30^{\circ} \mathrm{C}$ 'de rahatlıkla gözlenmektedir.

Aynı örneklerin DTA analiz sonuçları FDM de tespit edilenlerden daha düşük sıcaklık noktaları olmuştur. Formülasyon örneklerinin Zsin eğrileri değerlendirilmemiştir. Farklı konsantrasyonlardaki sukroz solusyonları ve aşı ürünü ile beraber hazırlanmış formülasyon örneklerine ait DTA analiz sonuçları arasındaki en büyük fark ise $3,81^{\circ} \mathrm{C}$ olarak bulunmuştur. Bu sicaklık farkı trehalozun yer ald1ğ formülasyon örnekleri için 1,53 olarak mannitol için ise 0,58 olarak belirlenmiştir. S19 aşı suşu ile sukroz, trehaloz, mannitol solüsyonlarından hazırlanan formülasyon numunelerinin FDM ile DTA analizleri arasındaki en büyük sıcaklık farkları sırasıyla 4,$46 ; 5,6$ ve $3,68^{\circ} \mathrm{C}$ olarak gözlenmiştir.

Aşı ürünü ile birleştirilmemiş liyoprotektan solüsyonlarının FDM, DTA ve Zsin analizlerinde ve aşı ürünü ile liyoprotektan karışımı sağlanmış formülasyon örneklerininin FDM ve DTA analizlerinde konsantrasyon artışına bağlı kritik sıcaklıklarda çok büyük değişimlerin olmadığı gözlenmiştir.

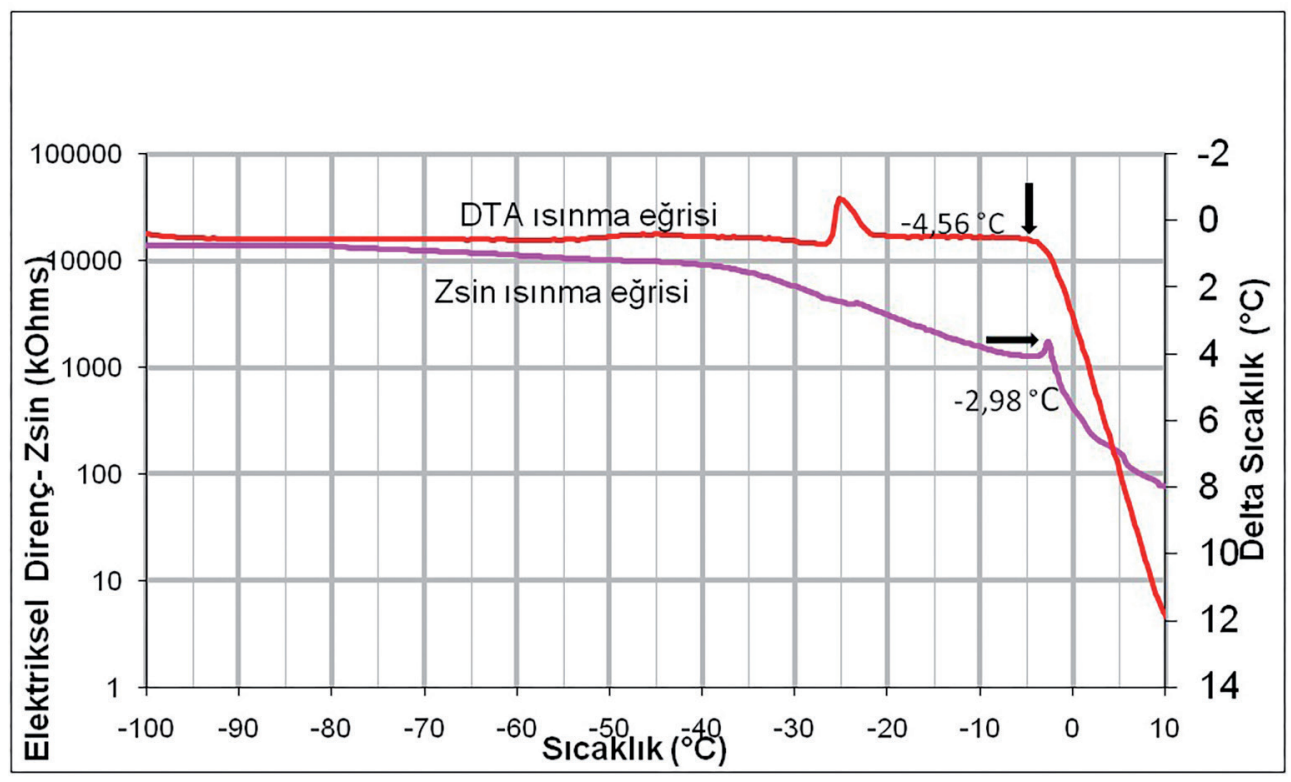

Grafik 1. \%15 Mannitole ait DTA ve Zsin analiz sonuçları. 


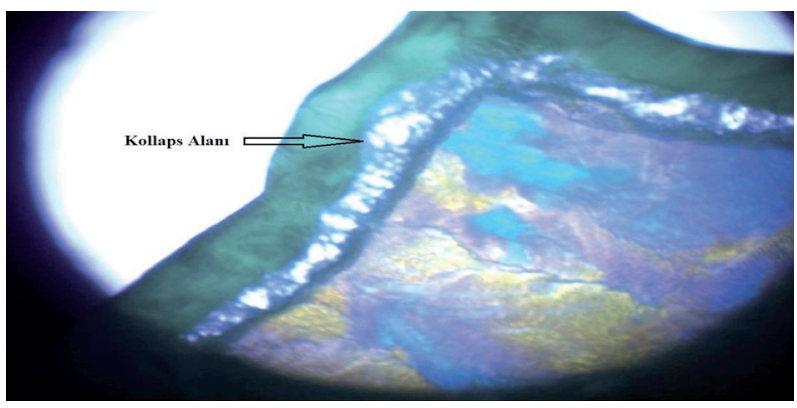

Resim 1. \%15 Sukroz + S19 aşı formülasyonu için kollaps alanı $\left(-30 \mathrm{C}^{\circ}\right)$.

\section{Tartışma ve Sonuç}

Liyofilizasyonda kullanılan yardımcı maddelerin kristalizasyon davranışlarını yansıtan Tc ve Tg' değeri liyofilizasyon prosesinin geliştirilmesinde dikkate alınan önemli fizikokimyasal karakterlerdir [10]. FDM görüntüleme sonuçları değerlendirildiğinde, aşı yarı mamulü ve farklı konsantrasyonlardaki yardımc1 ajanlar ile standart bir dilusyon oranına göre hazırlanmış formülasyonlarda kollapsın veya erimenin gözlendiği sıcaklıklar arasında majör farklılıklar gözlenmemiştir. Sukroz için farklı çalışmalarda Tc değeri $-32^{\circ} \mathrm{C}[8,19]$ ve $\mathrm{Tg} '-28^{\circ} \mathrm{C}[4,14]$ olarak belirtilmektedir. Trehaloz için $-28^{\circ} \mathrm{C}$ [13] ve $-30^{\circ} \mathrm{C}$ [18] $\mathrm{Tg}$ ' ve $-29^{\circ} \mathrm{C}$ ise $\mathrm{Tc}$ [1] değeri olarak paylaşılmıştır. Mannitol ise $-3^{\circ} \mathrm{C}$ olan daha yüksek bir Teu değerine sahiptir [24]. Paylaşılan bu sıcaklık değerleri ile FDM analizinden elde edilen sonuçlar karşılaştırıldığında sukroz, trehaloz ve mannitolde konsantrasyon artışına rağmen sırasıyla en fazla 1,$75 ; 2,47$ ve $2^{\circ} \mathrm{C}$ sıcaklık değişimleri gözlemlenmiştir. Birincil kurutma süresince sicaklığın kritik proses sicaklık değerlerini aşmamak üzere azami seviyede yüksek tutulması gerekmektedir. Birincil kurutmayı takiben ikincil kurutmada sıcaklığın yükseltilmesi, üründen donmuş kısım uzaklaşmadığında erimeye neden olabilir. Birincil kurutmanın bitiş sıcaklık noktasının tayini bu açıdan çok büyük önem taşır [8]. Bu açıdan tespit edilen sıcaklıklar birinci kurutmada optimum hedef sıcaklığının belirlenmesinde sağlayacakları yardımdan ötürü kayda değer sonuçlardır.

FDM sonuçları görüntüleme cihazında elde edilen resimlerin değerlendirilmesi sonucu kayıt edilmiştir. Böylece FDM de tespit edilen Tc sicaklığının başlangıç veya tam kollaps işaret edebildi- ği paylaşılmıştır. Aynı zamanda FDM cihazının başlangıç kollapsının belirlenmesinin subjektif bir değerlendirme temeline dayanmakta olduğu belirtilmiştir [10]. Bizim yaptığımız analizlerde gözlem kriteri olarak kollaps hattında göz ile rahatlıkla seçilebilen başlangıç noktalarını temel aldık. Bu sonuçlar reçete oluşturulmasında sadece kollaps ve erime sıcaklıkları temel alındığında yardımcı madde konsantrasyon artışına bağlı majör varyasyonlar içermeyen sıcaklık aralıklarının kullanılabileceği göstermektedir. Görsel olarak bir kollapsı gözlemleme olasılığının mikroskobun 1şık kaynağı ve polarizasyon filtresi ile sinırlı olduğu da unutulmamalidır [15].

Aş1 yarı mamulü ile yardımcı madde formülasyonlarında DTA eğrilerinde görülen pik noktaları farklı konsantrasyonlarda dahil olmak üzere FDM cihazında tespit edilen kollaps sıcaklıklarından daha düşük sıcaklıkları işaret etmektedir. DTA analizinde gözlemlenen ekzotermik pikler donmuş materyal içinde stabilizasyon ve yeniden düzenlemeyi göstermektedir [3]. Bir diğer çalışmada benzer olarak ürün Tc değeri -18,6; -17,4 olarak tespit edilmişken DTA cihazı ile aynı ürün için impedens analizine göre -25 derecede ürün formunda bir yumuşama gözlenmiştir [22]. Ayrıca aynı liyoprotektan ve konsantrasyon için Tc ile Tg' ve Teu sıcaklıkları arasındaki söz konusu tespit edilen farklar için cihazlar arasında çalışma prensibi ve sonuçların değerlendirme metodu farklılığının göz önünde bulundurulmas1 tavsiyesi ortaya konulabilmektedir.

Tc ve Tg', her iki değer de ürün sicaklığının (Tp) üst limitini belirlemeye yardımcı olmaktadır. Tc değerleri genellikle $1-3^{\circ} \mathrm{C}$ Tg' değerinin üstünde olduğu ve Tc değerinin üzerinde bir kurutmanın makrokollaps ile sonuçlanabileceği belirtilmiştir [10]. Bir başka yayında ise Tg' ve Tc aynı deneysel parametreleri temsil etmedikleri açıklanmış ve Tc değerlerinin genellikle ilişkili Tg' değerlerinden $2-5^{\circ} \mathrm{C}$ daha yüksek olduğu raporlanmıştır [15]. Bizim çalışmamızda bahsedilen yayın sonuçlarındaki benzer sıcaklık farkları gözlemlenmiştir. $\mathrm{Bu}$ sıcaklıkların aşı yarı mamulü ile yardımcı madde karışımlarında devam ediyor olması, reçete dizaynı açısından göz önünde bulundurulması faydalı bir bulgudur. Zira gözlemlenen Tc ve Tg' değerleri arasındaki korelasyonun yorumlanmasını kolaylaştırabilir. Tg değeri için unutulmaması gereken nokta 
Tg’ nin bir sicaklık aralığı olduğu ve tek bir sıcaklık noktası olmadiğıdır [15].

Dondurarak kurutma uzun sürmesi nedeni ile oldukça pahalı bir proses olduğu için proses gelişiminde, en uzun süren birincil kurutma süresinin asgariye indirilmesi anahtar rol oynar. Fakat buzun tamamı üründen uzaklaşmadan ikincil kurutma aşamasında kollaps sıcaklığının üzerinde ürün sıcakl1ğındaki artış büyük olasılıkla kollaps veya ötektik erimeye neden olmaktadır $[12,20]$. Bu açıdan $B$. abortus S19 aşılarının liyofilizasyonunda, çalışmamızda tespit edilen kritik sıcaklıklarının, göz önünde bulundurularak sicaklığın yükseltilmesi kollaps veya ötektik erimeyi önleyebileceği öngörülebilmektedir.

Çalışma sonucunda FDM cihazı ile Tc ve DTA ile de Tg' veya Teu belirlenmiştir. Tg' değerinde ama Tc'nin altında kurutma yüksek konsantrasyondaki protein formülasyonları için kullanılabilmektedir [10]. Sukroz ve trehaloza kıyasla aşı yarı mamul ürünü ile mannitol karışımı için elde ettiğimiz daha yüksek ötektik sıcaklık değerleri liyofilizasyon reçetesinin oluşturulması daha geniş güvenli sıcaklık aralıkları sunabileceğine işaret edebilmektedir. Kristalin mannitolun, tek başında $-40^{\circ} \mathrm{C}$ 'de sukrozda gerçekleşen kollapsı, beraber kullanıldığında $-10^{\circ} \mathrm{C}$ kuruyan sukroz yapısında önlediği bir raporda paylaşılmıştır [23]. Çalışmamızda gerek FDM ile gözlemlenen Tc ve gerekse DTA ile elde edilen Tg' veya Teu değerlerinde konsantrasyon değişikliğine bağlı yüksek sıcaklık farkları gözlenmemiştir. Benzer bir çalıșmada da farklı konsantrasyonlardaki $(\% 5, \% 10, \% 20)$ sukroz ve trehaloza ait DSC (Diferansiyel Taramalı Kalorimetri) analizlerinde belirlenen $\mathrm{Tg}$ ' değerinde $1^{\circ} \mathrm{C}$ 'den daha az sıcaklık farklı11kları gözlenmiştir [10]. Bu nedenle tercih edilecek protektan ajanın belirli seviyedeki yüksek konsantrasyonlarının kullanımı halinde bile çalışma numuneleri ve izlenen metoda göre prosesin yakın kritik sıcaklıklarda sürdürülebileceği düşünülmektedir. Bu sayede daha fazla koruyucu ajan ile ürünün çevrelenmesinin sağlanabilmesi liyofilizasyon kaybını azaltan bir avantaj sağlayabilecektir. Zira mevcut uygulamada ürün güvenliği ve kalitesi ad1na proses dizaynı, ürün sıcaklığ 1 için $2-5^{\circ} \mathrm{C}^{\prime}$ lik bir güven aralığı ile ilişkili olarak belirlenmektedir. $\mathrm{Bu}$ aralık üretim hacminin yükseltilmesinde, teknoloji transferinde ve farklı liyofilizator kullanımında küçük değișikliklere olanak sağlamaktadır [17,27]. Liyofilizasyon başından sonuna kadar bağlantılı bir proses olarak yorumladığımızda konsantrasyon artışının ikinci kurutma için de etkisini değerlendirmek gerekebilir. S1klıkla birincil kurutma sırasında üründe kollaps oluşma ihtimali ikincil kurutmaya kıyasla daha fazladır [5]. Çünkü birincil kurutma sonrası ürün içeriğinde su miktarı daha düşük seviyelerde bulunmaktadır. Fakat ikincil kuruma koşulları ayrıca çözünen maddenin konsantrasyonuna bağlıdır. Çözünen maddenin konsantrasyonu yüksek olduğunda, emilen suyun çıkarılması daha zor hale geldiğinden, ikincil kurutma daha uzun zamanda veya daha yüksek sıcaklıkta gerçekleşir [6]. Bu nedenle protektan ajanın daha konsantre halde kullanılmas dolaylı olarak ürün-protektan formülasyonun katı madde içeriğini yükselteceği için liyofilizasyon prosesi verimliliğini ve sürdürülebilirliğini olumsuz yönde etkileyebilir.

Dondururak kurutma prosesinde ölü veya canlı organizmalar, enzimler, hormonlar, organ ekstraktı gibi materyaller, hassas biyolojik materyaller olarak kabul edilmiştir. Kurutmada zorluklara neden olan preperasyonlara örnek olarak da aşılar gösterilmiştir [25]. Bu açıdan çalışmamızda elde edilen sonuçlar, Brucella abortus S19 aşı suşu temel alınarak liyofilize aşıların reçete optimizasyonu için daha geniş güvenli kurutma sıcaklık aralığını sağlayacak liyoprotektanın seçimi ve bu ajanın konsantrasyonunun belirlenmesi yönünde temel bir basamak oluşturmuştur.

\section{Kaynaklar}

1. Adams GDJ, Cook I,Ward KR, (2015). The Principles of Freeze-Drying. WF Wolkers, $\mathrm{H}$ Oldenhof eds. Cryopreservation and Freeze-Drying Protocols. Springer, New York. p.121-143.

2. Alton GG, Jones LM, Angus RD, Verger JM, (1988). Techniques for the Brucellosis Laboratory. Institut National de la Recherche Agronomique, Paris, France.

3. Bandari S, Seshasai M, Reddy YRC, (2013). Optimization Of Lyophilization Cycles for Gemcitabine. Int J Pharm Pharm Sci. 5(2), 216-221.

4. Carpenter JF, Pikal MJ, Chang BS, Randolph TW, (1997). Rational Design of Stable Lyophilized Protein Formulatinons: Some Practical Advice. Pharm Res. 14(8), 969-975.

5. Day JG, Stacey GN, (2007). Cryopreservation and FreezeDrying Protocols, Human Press, New Jersey.

6. Deepak B, Iqbal Z, (2015). Lyophilization-Process and Optimization for Pharmaceuticals. IJDRA. 3(1), 30-40. 
7. Franks F, (2007). Freeze-drying of pharmaceuticals and biopharmaceuticals, RSC Publishing, Cambridge.

8. Gaidhani KA, Harwalkar M, Bhambere D, Nirgude PS, (2015). Lyophilization/FreezeDrying - A Review. WJPR, 4(8), 516-543.

9. Hajare AA, More HN, Walekar PS, Hajare DA, (2012). Optimization of Freeze Drying Cycle Protocol Using Real Time Microscopy and Integrated Differential Thermal Analysis-Electrical Impedance, Research J Pharmand Tech. 5(7), 985-991.

10. Horn J, Friess W, (2018). Detection of Collapse and Crystallization of Saccharide, Protein, and Mannitol Formulations by Optical Fibers in Lyophilization. Front Chem. 6(49), 1-9.

11. Jenings AT, (1999). Lyophilization, Introductionand Basic Principles. CRC Press, Taylor and Francis Group, USA.

12. Karagul MS, Altuntas B, (2018). Liyofilizasyon: Genel Proses Değerlendirmesi Etlik Vet Mikrobiyol Derg. 29(1), 62-69

13. Kasper JC, Friess W, (2011). The freezing step in lyophilization: Physico-chemical fundamentals, freezing methods and consequences on process performance and quality attributes of biopharmaceuticals. Eur J Pharm Biopharm.78, 243-268.

14. Lueckel B, Bodmer D, Helk B, Leuenberger H, (1998). Formulations of sugars with amino acids or mannitol - influence of concentration ratio on the properties of the frezeconcentrate and the lyophilizate. Pharm Dev Technol. 3(3), 325-336.

15. Meister E, Gieseler H, (2008). A significant comparison between collapse and glass transition temperatures. European Pharmaceutical Review. Erişim: [https://www. europeanpharmaceuticalreview.com/article/1479/a-significant-comparison-between-collapse-and-glass-transitiontemperatures/], Erişim tarihi: 15.04.2018.

16. Meister E, Gieseler H, (2009). Freeze-Dry Microscopy of Protein/Sugar Mixtures: Drying Behavior, Interpretation of Collapse Temperatures and a Comparison to Corresponding Glass Transition Data. J PharmSci, 98(9), 3072-3087.

17. Mikal MJ, (2010). Mechanisms of Protein Stabilization During Freeze Drying Storage: The Relative Importance
Thermodynamic Stabilization and Glassy State Relaxation Dynamics. L Rey, JC May eds. Freze Drying/Lyophilisation of Pharmaceutical and Biological Products. Informa Healthcare, London. p. 198-232

18. Nail SL, Her LM, Proffitt CPB, Nail LL, (1994). An improved microscope stage for direct observation of freezing and freze drying. Pharm Res. 11, 1098-1100.

19. Oetjen GW, (1999). Freze drying. Wiley-VCH, German.

20. Patel SM, Doen T, Pikal MJ, (2009). Determination of End Point of PrimaryDrying in Freeze-Drying Process Control. AAPS Pharm Sci Tech. 11(1), 73-84.

21. Rey L, (2010). Glimpses into the Realm of Freeze-Drying Classical issues and New Ventures. 1-28. L Rey, JC May edse. Freze Drying/Lyophilisation of Pharmaceutical and Biological Products. Informa Healthcare.London.

22. Ross C, Gaster T, WardK, (2008). The Importance of Critical Temperatures in the Freeze Drying of Pharmaceutical Products. Erişim: [http://www.biopharma.co.uk/wp-content/uploads/2010/07/importance critical temps.pdf], Erişim tarihi: 08.10.2018.

23. Searles JA, (2010). Freezing and Annealing Phenomena in Lyophilization. L Rey, JC May eds. Freze Drying/ Lyophilisation of Pharmaceutical and Biological Products. Informa Healthcare. London.

24. Tang XC, Pikal MJ, (2004). Design of Freeze-Drying Processes for Pharmaceuticals: Practical Advice. Pharm Res. 21(2), 191-200.

25. United States Patent Office, (1959): Use of dextran in frezedrying process. 2,908,614.

26. Wang DQ, (2010). Formulation Characterization. L Rey, JC May eds. Freze Drying/Lyophilisation of Pharmaceutical and Biological Products. Informa Healthcare. London. p.233-253

27. Ward KR, (2010). The Use of Microscopy, Thermal Analysis, and Impedance Measurements to Establish Critical Formulation Parameters for Freeze-Drying Cycle Development. L Rey, JC May eds. Freze Drying/ Lyophilisation of Pharmaceutical and Biological Products. Informa Healthcare. London. p.112-135. 